\title{
An Environmentally Friendly Integrated Development Approach for Nepal (Experiences from Irrigation Sector Projects)
}

Achyut Man Singh

Abstract: Nepal has distinctly three ecological regions: (i) high mountain, (ii) mid-hills, and (iii) terai with their varying climatic and physiographic features. The experiences gathered from Irrigation Sector Projects implemented under various donor agencies such as the World Bank (WB), Asian Development Bank (ADB), and UN/ILO have shown that successful irrigation projects must be defined and planned according to specific ecological regions and pertinent to the local environment. An integrated development approach considers the land use, roads, market, and other economic activities as they relate to prospects for poverty alleviation. Land evaluation and subsequent land use planning according to the soil, climate, land profile, and suitability of agriculture practices should be considered in the development works to ensure true benefit to the rural populations. The integrated approach as such will provide long term sustainability through environmentally sound practices. This approach has been widely applied in the European countries, Korea, Japan, and Sri Lanka.

This paper primarily focuses on the irrigation and development approaches most suitable to Nepal's three ecological regions. High mountain regions should be developed with pasture land, horticulture, organic vegetable farming, and tourism. Irrigation technology in these areas should be simple pipe conveyance, and tank irrigation. In the mid-hills horticulture on the sloping terrain and cereal crops in the river valleys with other diversified cropping systems should be applied. The Terai region is the 'Bread Basket' of Nepal, and has high potential for diversified agriculture and industrial development.

For development in these regions to succeed, road networks and transportation facilities are essential to economic growth. Road transportation maximizes opportunity for tourism and other economic activities. Development work must be planned in an integrated approach, which should be based on appropriate land use patterns for environmentally sustainable practices. An ideal solution would be to envision the watershed as the unit for eco-friendly sustainable development planning involving all the stakeholders under the watershed purview. As an example, the principles of Integrated Water Resources Management Planning (IWRMP), and Integrated Watershed Management Plan (IWMP) have been successfully applied in the USA and Australia (Box 1). It has illustrated that vegetative covered catchment stores large amount of rain water, increases groundwater table, reduces erosion of soil, and lastly decreases the intensity of flood hazard. Whereas, the naked catchment areas are highly erodible, does not store rain water, susceptible to high erosion and land slides, and increases the flood intensity by three fold than a vegetative covered one. The vegetative cover increases the water resources availability for over all development for agriculture.

Keywords: Irrigation project Environmentally Friendly, Irrigated Development Approach, sustainable development

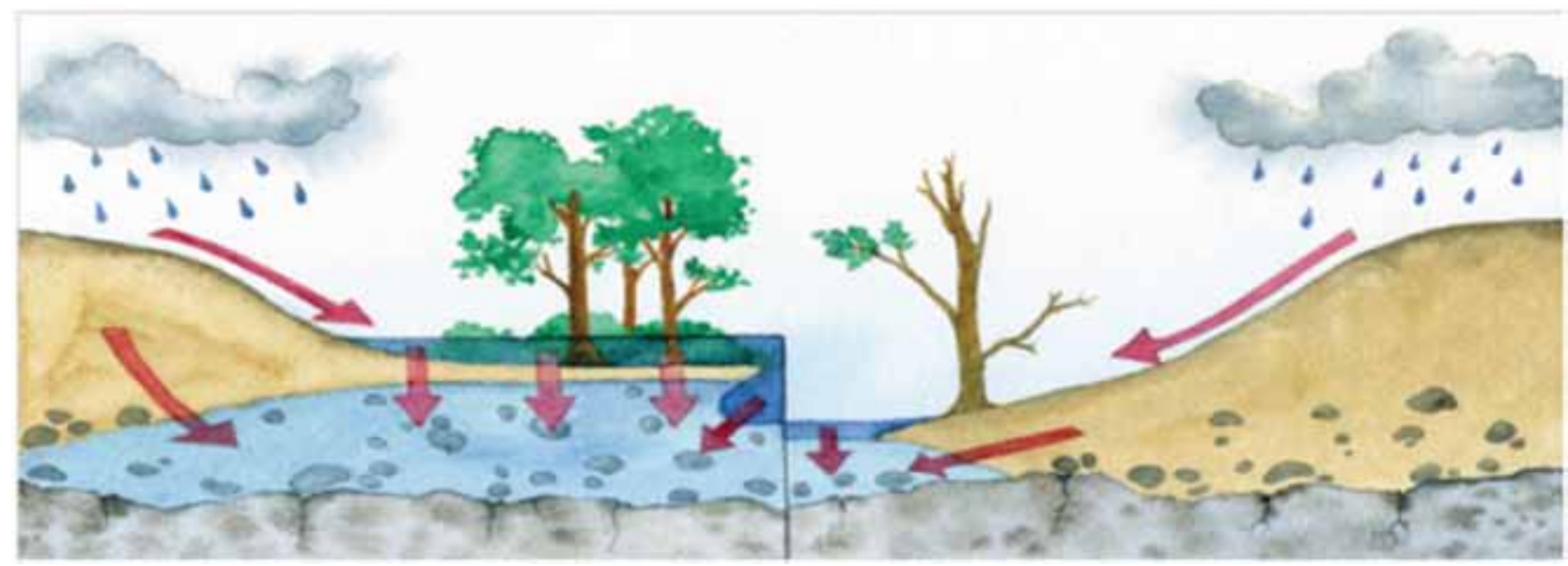

Source: Integrated Watershed Management Planning (IWMP), Manitoba Water Stewardship, USA. Box 1: Effects of Vegetative and Non-vegetative Catchment coverage on environment

\section{Background}

$\mathrm{N}$ epal has distinctly three ecological regions with its varied climatic and physiological features.
Sharply varied topography between the elevation of about $100 \mathrm{~m}$ in the southern border on the Gangetic plain to the highest peak of $8840 \mathrm{~m}$ (Mt. Everest) on 
the northern Tibetan border, bestow it with varieties of climate (see Figure 1). In general physical features, Nepal can be distinguished in three types as (i) High Mountain (Himalaya and its inner valleys), (ii) Mid-Hills (Midland hills and Mahabharat range), and (iii) Terai (Gangetic Plain and inner valleys). Their climatic variations are Arctic and arid in the Himalayan valleys, temperate in Midland hills and its valleys, and sub-tropical in Terai and its inner valleys (See Table 1).

\begin{tabular}{|l|l|l|}
\hline Region & Physiographic Division & Climate Regimes \\
\hline $\begin{array}{l}\text { H i g h } \\
\text { Mountain }\end{array}$ & $\begin{array}{l}\text { Himalaya and its Inner Valleys } \\
\text { Himalayan Southern face }\end{array}$ & $\begin{array}{l}\text { Arctic + Arid } \\
\text { Alpine }\end{array}$ \\
\hline Mid Hills & $\begin{array}{l}\text { Midland Hills, Tectonic Valleys, } \\
\text { and Mahabharat Range }\end{array}$ & Temperate \\
\hline Terai & $\begin{array}{l}\text { Siwalik Range, Terai and inner } \\
\text { Valleys }\end{array}$ & Sub-tropical \\
\hline
\end{tabular}

Source: $\quad$ World Atlas of Agriculture, By Gurung H., published by International Association of Agriculture Economics. Vol. 2, page 396. Novara.

Table 1: Climatic variations in the regions of Nepal.

The potential impacts of development work on agriculture, agro-industries, and other sectors such as tourism and mining have not been compared to other countries such Africa and Asia. However, the potential benefits to Nepal have not yet been satisfactorily exploited and utilized due to a lack of vision and commitment from subsequent governments. In that light, this paper presents data from the 1990 to present.
Considering the setting of its physical features, including climatic and social environments, the development strategy and its planning must be focused to address these regions with appropriate technology in agriculture and irrigation. Development work in agriculture and irrigation sector alone cannot resolve the poverty situation of the regions, which, need an integrated approach to include other sectors such as transportation, marketing, agro-industry, and tourism. In order to plan overall economic development in these regions, one must have a clear understanding of the physical features of these three ecological regions including their limitations. The integrated development approach should be directed to alleviate the poverty. However, first priority should be to address food deficits and subsistence living through the development of agriculture and irrigation sector improvements with appropriate modern technology. Past experiences of the Department of Irrigation, and irrigation-related INGO's should be considered.

\section{High Mountain (The Great Himalaya and its inner Valleys)}

This zone covers the northern high mountain regions having varying altitudes between 2,000 $\mathrm{m}$ to 8,848 $\mathrm{m}$ above mean sea level. Cultivation is practiced up to $3,500 \mathrm{~m}$ elevation. So there are limited lands available for cultivation in this zone. The southern face of Himalaya is covered with dense forest and experiences high precipitation whereas the inner valleys have very low rainfall. The area has temperate climate with dry

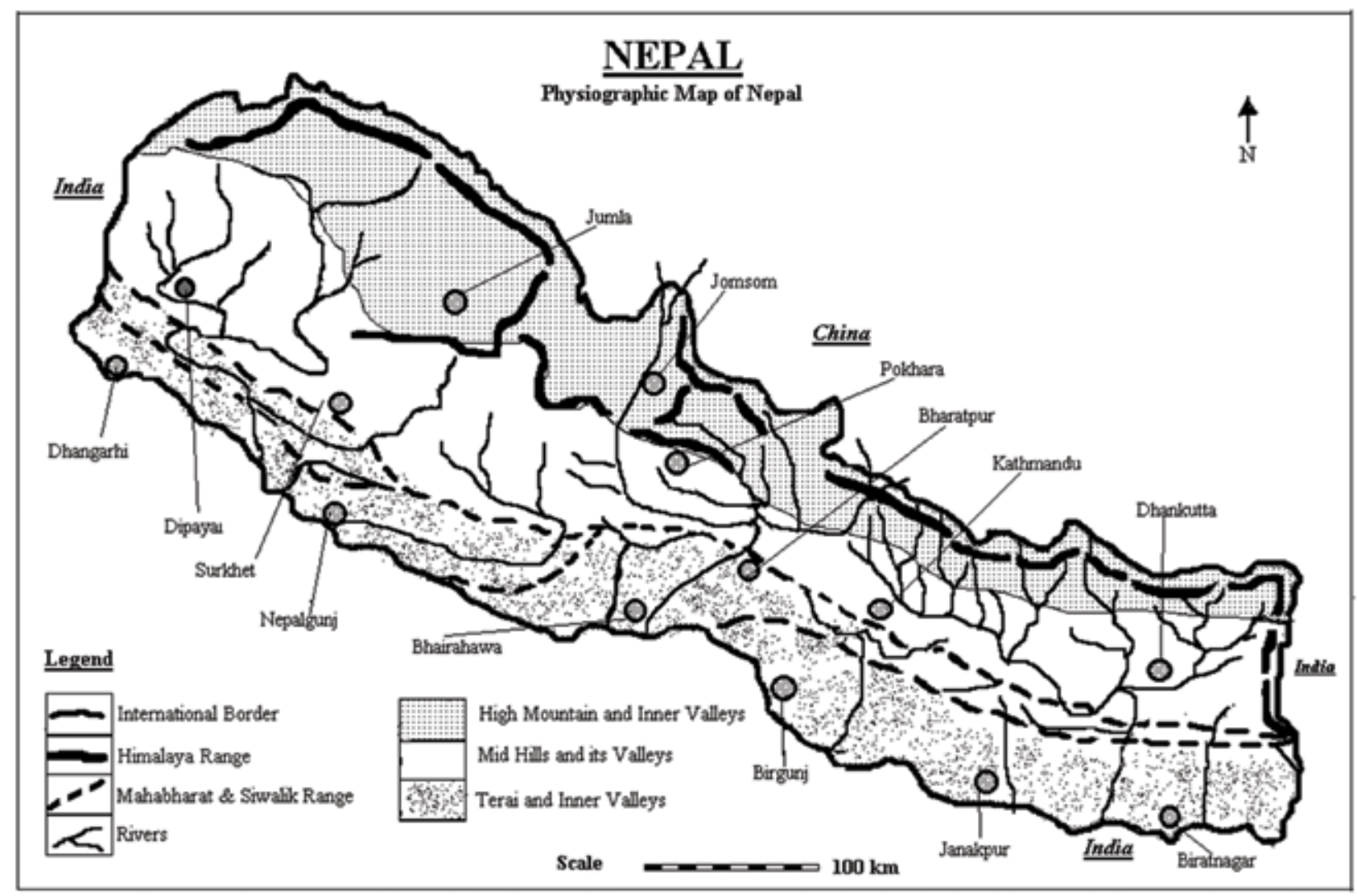

Source: Water Management Manual, Nepal Irrigation Sector Project (NISP), Under Department of Irrigation (Dol) and World Bank (WB), Government of Nepal (GoN).

Figure 1: Physiographic setup of Nepal 
and arid environment due to lee ward effect. The valleys are thinly inhabited and green areas can be found only near the villages where irrigation water is available. Pasture lands are available at high altitude near the snowlines.

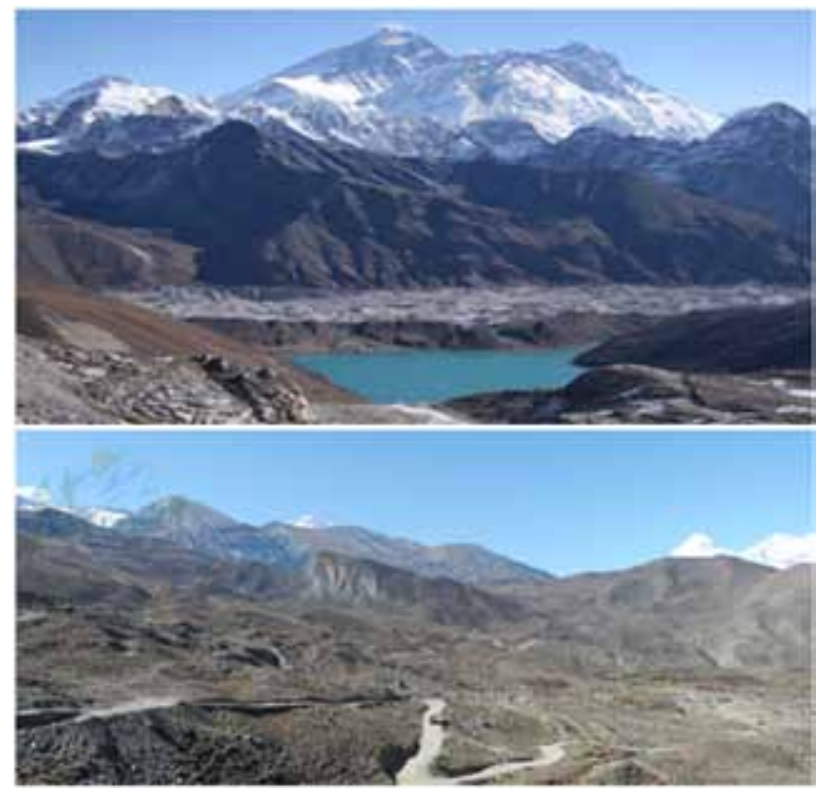

Photo 1: The Everest, the Great Himalaya and Mustang Valley, Inner Valleys

\section{Mid Hills (Mid land hills and their inner valleys)}

This belt of midland hills covers the central strip of the country comprised of numerous low hills, river valleys, and tectonic valleys. Most of these lands are fertile and have sub-tropical to temperate climate. The famous valleys of Kathmandu, Pokhara, Surkhet, Dang and Dipayal lie in this zone. Agriculture is the main occupation of the population. The area is densely populated inhabited by 48 percent of the total population of Nepal.

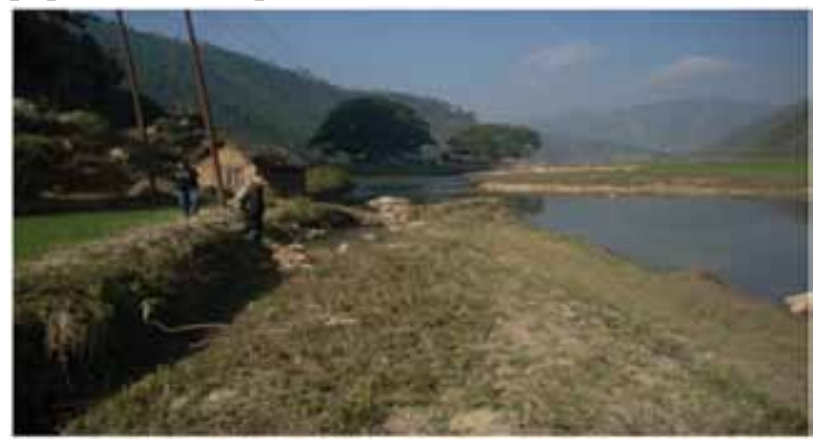

Photo 2: Mid Hills and its Valleys

\section{Terai (Gangatic Plain)}

This ecological belt has flat terrain stretching from east to west direction along the southern border with India. The strip is a part of Gangetic Alluvial Plain formed under alluvial deposit of River Ganga and its numerous tributaries. The width of the plains area varies between 25 to $30 \mathrm{~km}$ from the foot hills to the Nepal-India border.

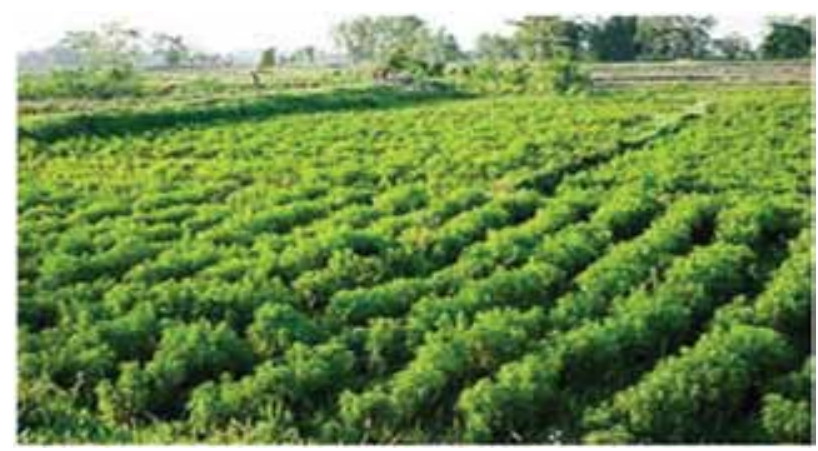

Photo 3: Terai-gangetic Plain

\section{Development Approach}

Sustainable development in agriculture using environmentally friendly technology can be obtained only when a proper land use evaluation and its proper management has been made. Land use evaluation and planning has always been neglected in this country. A proper use of landscape with cultivation in the mild sloppy lands and in valleys, steep sloped lands being utilized for forest reserve, pasture land for barren and wastelands needs to be developed to achieve sustainable and environmentally friendly practices in agriculture. Several INGOs and NGO's have carried out isolated programs on the sustainable watershed management, agro-forestry, and other small-scale income generating activities. However, a long-term planning on land evaluation with proper study on soil type and its suitability for land use has never been applied.

Land use planning and applying development works suitable to its potentiality is the only right solution to keep environmentally friendly and lasting for the generation to come. In the High Mountain, the population is thin and development options are limited. In the case of mid hills, the degradation of land and its natural resources are high, which needs urgent attention in this aspect. In Terai, the growing population has encroached the forestlands discriminately endangering the environment. In such a scenario, an overview of the development approach could be conceived per the ecological regions.

\section{High Mountain Zone}

This zone has always been a food deficit area, due to mono-crop a year cultivation, low rainfall, and inaccessible for conventional transport facilities. Population prevailing is thin, apart from agriculture farming, livestock and trade are their main occupation. Irrigation system is an integral part of their life as no crop is possible without irrigation. Snow fed streams and spring are tapped for irrigation. Vegetation is also thin due to lack of sufficient rainfall and excess grazing by the livestock. The topography is hostile and fragile; development works are difficult to apply due to its remoteness and fragile environment. A conceptual development approach has been proposed below with the following limitations.

- Light materials easy for transportation are only possible to use for the infrastructure construction. 
Remoteness and expensive air transport availability warrants to take light simple technology. PVC pipes and plastic sheets are generally used for canal water conveyance instead of cement use.

- Low rainfall area, lack of vegetation, lack of proper fuel wood, and low production prevail. People in this area migrate to lower hills in search of food and job during winter.

- Arable lands are limited and there is limitation in the production level too. Only one crop a year is produced. Therefore, the food production warrants that the population cannot be fed without outside supply.

- Only possibility to resource generation is the livestock production, wool and if managed properly, tourism. But there are least other chances that we could do any external inputs at the present context to make them self-sufficient in food production.

- Depletion of forest due to high fuel requirements is another constraint. Growths of vegetation in these areas are extremely slow. So, forestation and regeneration of vegetation also is out of question. Only way of development is the pasturelands and if possible some species of fodder grass, and medicinal plants.

\section{Proposed Development Technologies}

\section{Pasture Land Development and Management}

Overgrazing of pasturelands has resulted to scarce areas where the livestock could get proper fodder. Management of the pasture lands is a possibility by allowing grazing to limited and controlled areas only and shifting the grazing site in rotations by years.

\section{Livestock Management}

The livestock management could be introduced with improved technology and breeding technique.

\section{Herbal Production, Protection and Conservation}

Valuable herbs are available in this region, which needs controlled picking and export. Development of the natural herbal production technology is a possibility. Dabur Nepal has taken a land in lease at Marpha village of Mustang district to develop the herbal production. The naturally available herbs of the regions like "Yarchagumba" and "Paach aaule", and others should be conserved and controlled harvest should be introduced.

\section{Horticulture Development}

Fruits like apple, pears and grapes are produced in large quantity in this region. Transportation and marketing have been the main constraints in developing this farming and benefiting the farmers in this region. Cost effective transportation facilities and marketing would boost up the farming communities.

\section{Argo-industry}

The fruits could be processed and proper management could be made to develop and support the fruit production.

\section{Organic Vegetable and Improved Seed Production}

The climatic conditions are most suitable for organic vegetation, which could be transported to markets for high value cash crops. In addition to, improved seed production also is potentiality to enhance the economic living standard of the areas.

\section{Tourism Development}

The tourism industry has been a viable option for the development of the region, which has already been proved in the past. The recent instability in the country has hampered the tourism industry, However there are ample potential for its development in the future, if the situation improves.

\section{Possible Irrigation Technology Suitable for this Region}

The experience of the past irrigation projects in this region has given defined technologies which are suitable for this region;

- PVC pipes conveyances systems,

- Improvement of the traditional tank irrigation (Reservoir systems - 'Ching') by applying plastic lining and cement mortar. The technology has been successful in the Nepal Irrigation Sector Project in Mustang District,

- Introducing sprinkler and drip irrigation systems making it economically viable options,

- Low cost soil cement and plastic lining technology for the conveyance canals.

\section{Mid-Hill Zone}

Agricultural cultivated lands in mid-hills have two types of land use - Upland as 'Bari' and Lowland as 'Khet'. In local terms bari means generally rain fed cultivated lands where non-rice crops as maize, finger millet and other beans are grown. The lowland cultivated areas are termed as 'Khet', which means paddy field prepared in terraced parcels or plain parcels forms. In Khet paddy crops are generally grown in the monsoon period, during other seasons other crops are grown depending on the irrigation facilities available. In this zone, arable lands also are limited as in the case of High Mountain. Rain fed 'Bari' does not produce adequate quantity of food grains, and combined with the 'Khet' the production of Mid-Hills also do not meet the requirements to sustain the population pressure. The population density in Mid Hills is high 5 to 7 people per ha of the cultivated area. The production limit in the rain fed condition is 2 to 3 ton per ha, where two crops a year are grown-Maize and finger millet in general. The chances of crop failure are high due to uncertainty of the rainfall pattern as dry spells frequently exceed two weeks. Utmost 2 tons per ha production can be achieved in the rain fed cultivated areas. This production level is marginally enough to sustain living for 5 to 7 people per ha. Therefore, farmers living in the rain fed conditions are basically living for survival only, other requirements for health, education and others are out of question.

\section{Identification of the Constraints in Mid Hills}

- Population growth is the primary factor of Mid-Hills.

- No other economic activities are performed at this region except agriculture. And it is mostly traditional 
cultivation with improved crops at approachable places.

- Depletion of forest has reduced the base flow of water sources and thus irrigated areas are also shrinking at hills. Another effect of forest depletion is the bank erosion by streams, which had become wider than in
In urban places, most of the skill works are done by Indian skill laborer, while unskilled Nepalese seek jobs in India as porters, guards, waiter, chaukidars, etc.

\section{Possible Development Approach}

- The government must carry out an intensive work
Cattle Population

a Cattle Population

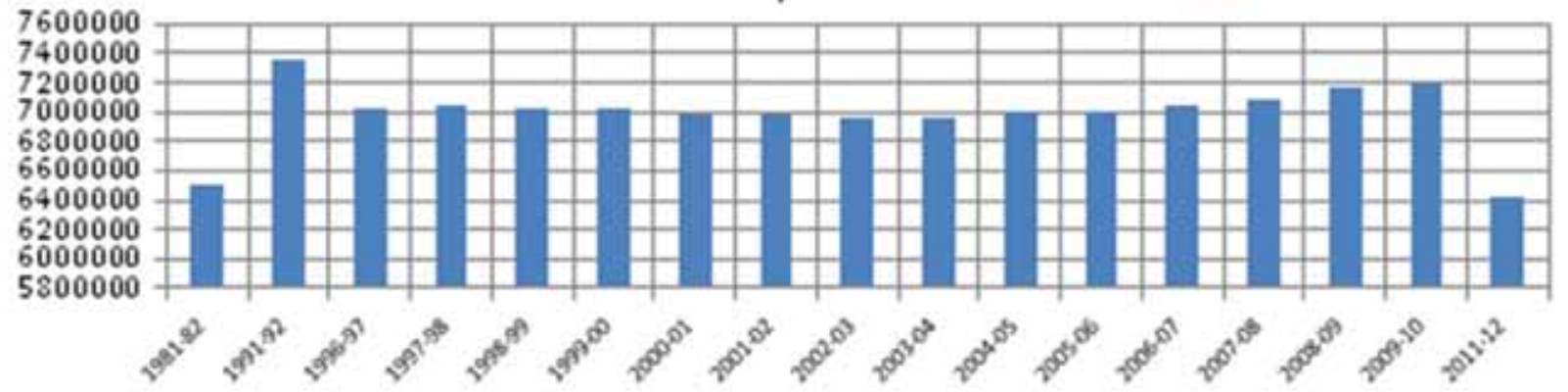

Source; World Development Indicators, World Bank

Box 2: Cattle population in Nepal

\section{Forest land Area By Year}

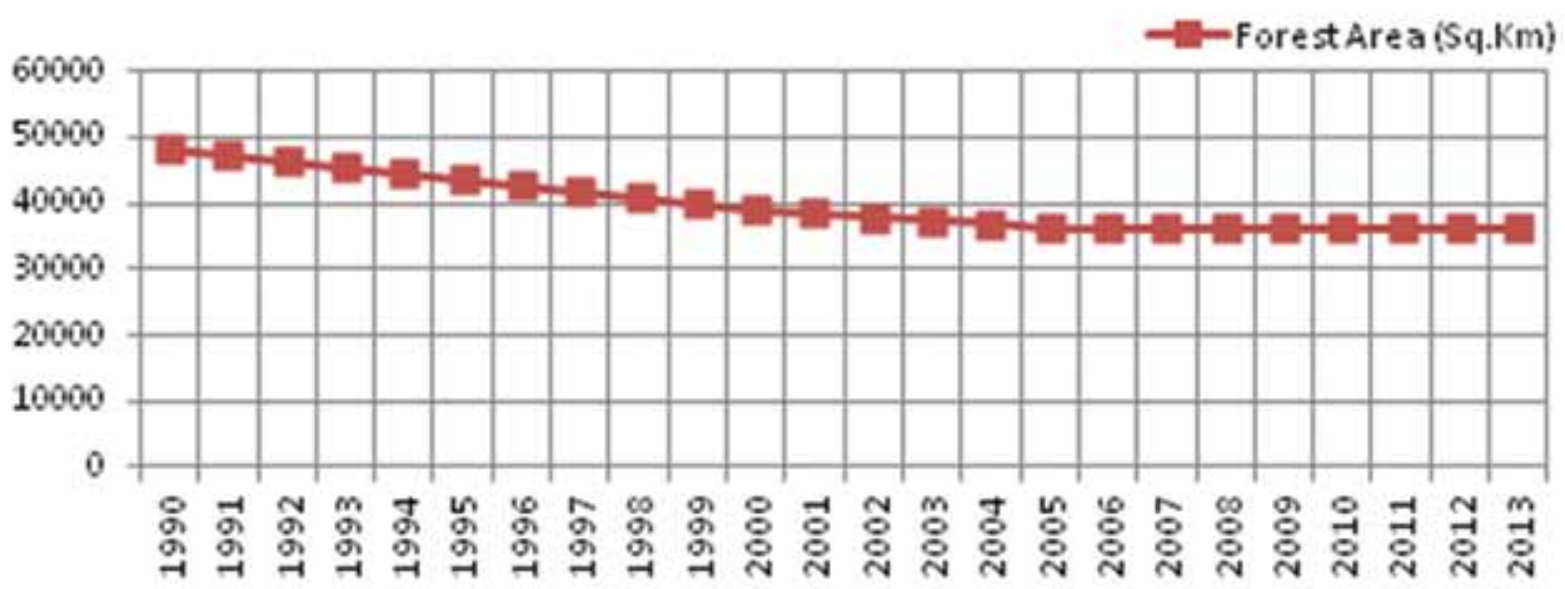

Box 3: Forest area coverage

Source; World Development Indicators, World Bank

the past (See Box 2).

- Depletion of livestock reducing organic manure and unavailability of chemical fertilizer caused low productivity of the land and thus the yield. The stagnant yield or decreasing yield rates of maize are the effect of low productivity of the mid-hill cultivated lands.

- Population could not be fed with the local food grain production. This scene is precarious that the people migrate as temporary laborers to India,third countries and Terai from mid-hills.

- The hilly populations of Far-West, Mid-West, and from Western Hills migrate temporary to India for subsistence. In contrary, labor from neighboring State of India have fulfilled the deficit agriculture labor requirements at Terai belt. Movement of laborers to and from India is not monitored.

- The poor laborer and farmers have no other skills than to carry loads as porter from one place to other. to identify and register its citizen at Terai as well as hills and mountain. After thorough identification and registration only, programs could be launched to benefit and welfare the poor mass. Without obtaining proper record how one can manage to feed or to give welfare subsides. In Terai the open border with India has direct effect in monitoring the population identification, the task is most challenging, and however for national interest it is worthwhile to initiate such activities.

- Strict rules and regulation enforcements are another factor, which are prerequisites for any development works. Indiscipline society and weak law and order situation warrant anarchy and there is no hope for any development. The donors for development also are in watch and wait situation to invest extensively in Nepal due to its unstable governance system.

- The development work to target the poor population must be prepared incorporating all the dimension of 
the effects. Integrated approach from food production to market must be studied and designed based on practical experience and situation. Poor attention on local manure and giving high importance in applying chemical fertilizers resulted to very low livestock population, thus causing low application of manure, especially in the hills. The present scenario shows very low productivity at rural hills.

- Accessibility to farm land and market, for example, the Mustang Districts produced apple, peach production to its maximum level, but the products could not be sold in market, and used for manure and liquors production. Development works in one sector must be associated with all the other supporting components. If we talk about increasing production, it must be viable and profitable to farmers to carry out the activities to increase his production. For losses in investment, no farmer will use his effort and resources.

- Now, it is evident that road networks for transportation is essential for any fast development works. Recently engaged food for work programmed under UNDP, HELVETAS, GIZ and other assistance has developed roads to certain targets and are reported to be successful. However, the author feels that artery networks of all-weather roads is prerequisite which should be constructed with conventional engineering hi-tech methods, whereas the linking roads may be built with the local indigenous resources. For all out development, the artery roads linking major centers with the interior of the country must be developed for supporting any other developments. As market is vital for economic development, without transportation facilities the investment in development is meaningless. India where low cost roads have been developed successfully can be cited.

- In irrigation and agriculture sector the assistance must be focused for subsistence requirement with control investments. Where there is potential of market and all other facilities, the farmers must be protected and facilitated to enhance their production. Success stories of Dhading, Nepaese farmers along the Prithivi Highway could be taken as good example. However, the middle man buyers and transportation, and multi-layer sellers of the agri-production are exploiting the price setting to farmers and to the consumers. Farm house prices are sometimes more than 10 to 20 times less than the consumers' price at market. No control over the prices of vegetables and cereals in the prevailing markets especially in around the cities.

- Development of the 'Rainfed Tars' (River Terrace) along the banks of Snow fed Rivers. Most of the Mid-Hills River Terraces are rain fed and resided by the poor 'Subsistence Farmers'. Perennial water is flowing below about $100 \mathrm{~m}$ or less elevation. However, the farmers are facing acute shortage of water. Water harvesting with tank irrigation, pumping schemes from the river is a possibility. The Irrigation Development works must be accompanied with electricity and the road networks to facilitate the agriculture impact from the schemes. An integrated approach with cash crop development with deep pumping schemes needs to be explored. Long hilly surface canal like in Chapakot, Attrauli Puttar are not only economically unfeasible, but requires large funds for maintenance, and their sustainability is always in question due to fragile geological strata along the canal alignment.

\section{Terai-Gangetic Plain}

Terai has been the 'Bread Basket' of Nepal, and would be the basket for Nepal in future too. Food grains as well as other high value crops can be produced here, as it has great potentials and the required support services. Unlike the hills where the input supplies, technology and transportation are all hindrances for its agriculture development. There is limiting factor for production in hills and mountain and it should be matching with their environmental preservation. But in Terai, there is ample scope of development. It should be preserved and utilized properly for the country to feed the growing population.

Agricultural Perspective Plan (APP) has recognized to develop groundwater irrigation at Terai for yearround irrigation where it is applicable or have potential. The review on the present groundwater pumping schemes at Terai revealed that the cost of pumping is quite high and not economically viable to run it for conventional crops as paddy, wheat, maize. Unless the pumps are utilized for cash crops, the pumps are not profitable for use. Various constraints faced in Terai agriculture and irrigation sectors are presented below:

- Counterpart Indian Farmers are receiving highly subsidized fuel and electricity; therefore, the farmers in the Terai are compelled to compete with Indian counterpart in the market. With the open border, with no restriction for the import of agriculture production, the farmers are unable to compete in the market. These farmers need to be protected if at all the production and economic growth must be achieved at the farm level. The production boom in Terai Region shall indeed support the population of other region if these farmers are not in loss. Almost 100 percent of the Shallow Tube Well (STW) and Deep Tube Well (DTW) are running at low capacities less than 300 hrs. per annum. Cost effective running hours is computed 1,60o hours and above. Therefore, despite the technology and high potential of production at Terai. Government of Nepal policies must guard and protect the farmers against highly competent neighbor farmers of India.

- There is potential for irrigation development in Terai, which has been harnessed only one third of its total irrigable area. Large surface water schemes gravity irrigation is the right answer for this development, but these proposed schemes have been difficult 
to implement due to riparian issues with India. Government of Nepal own resources only could be utilized for this development. On the other side of Indian border, they have built all the possible large surface water schemes, which has been irrigating in millions of hectares of land. To foster agriculture production, this is one of the options that need to be considered.

\section{Modernization of the Large Farmers Managed Irrigation Systems in Terai}

There are still several large Farmer's Managed Irrigation Schemes (FMIS) in Terai which are operated by the farmers with their own resources and minimum grant assistance from the government. These are Sorah Chhatis Mauza and Chhar Tappa of Rupendehi, Rani Jammara and Kularia of Kailali districts in Nepal. These systems are irrigating thousands of hectares of land and needs modernization at the present context of the development, as they still apply the indigenous technology in diverting and distributing the water share to the farmers. Several others as Budhi Kulo and other systems of Rajapur are developed with the new technology; Praganna of Dang valley has been in the construction phase. However, there are still needs to be developed in the remaining large FMIS.

\section{Reconstruction and Revival of Defunct FMIS in Terai}

There are numerous FMIS in Terai, which were operational in the Jamindar System in Pre-Panchayat Regime. These are defunct and in non-operational condition at present. These systems should be developed up to the tertiary unit as in 'Sunsari Morang Irrigation System', keeping the spirit of Participatory Approach'.

\section{Groundwater Development in Terai to be focused in 'Rainfed Area' only}

Groundwater schemes are costly and require operation cost compared to surface scheme. The subprojects are not economically feasible unless it is used for cash crop development. Therefore, the development works could be applied in the rain fed areas where water is scarce and market is easily available. As the Indian counterpart controls the market of Terai, unless a policy change is made to protect the Nepalese farmers, the intensive cultivation with cash crop production will be slim.

\section{Industry based Agriculture Practices}

In Terai there are numerous possibilities to establish agro industries as sugar mills, cotton mills and more industries related to base. Several attempts have been made in this approach, however full scale development is lagging due to poor management of the agroindustries.

\section{Cold Storage Facilities Development}

It has been observed that cold storage facilities are not available to the farmers in the Terai belt, one in Bhairahawa is available, and there are none in other regions. The farmers are not able to cash their products properly due to the low-price competition of the neighboring Indian farmer's products. The cold storage facilities will support these farmers to take adequate measures to store the product and sell it with good prices in time.

\section{Supportive policies in providing compatible Subsidy policy in electricity, import of fertilizer, and levy on agriculture products from India}

The neighboring Indian farmers are receiving large subsidies in electricity and agriculture inputs. The Nepalese farmers cannot compete with these products as the open border and no custom charges make it easier to import from India. So, a reasonable subsidy policy will be required to make the Nepalese farmers capable enough to compete with them.

\section{Development of other Industries}

There are many opportunities to develop other industries at Terai. A proper policy would facilitate to develop viable industries at Terai.

\section{Cost Effective and easy Transportation Facilities}

The high costs of the Nepalese products are also due to high transportation cost. This could be improved by introducing Railway or other alternate methods of transportation. It needs to explore some possibility in future planning.

\section{Large Surface, Schemes Development}

Diverting the snow fed rivers for irrigation and hydropower in the inner valley and feeding the existing irrigation systems would secure the irrigable areas in Terai, as the local streams from Chure and Mahabharat range depleting fast due to rapid degradation of the catchments. Large surface irrigation systems development could be made to include large areas under year-round irrigation facilities.

\section{Proposed Irrigation Project Formulation}

Experiences from the (ILC, NISP, SIP, and SISP) ${ }^{1}$ sector projects have indicated that irrigation systems differ in their characteristics per the ecological regions, which largely depends on the topography and geological formation. Overall development strategies in these regions have been stated in the above paragraphs. In this chapter categorization and packaging of the development works are discussed.

\section{High Mountain Zone}

The Hill zone has complex and variable climatic and topographic regions. The sloppy upland areas and lowland areas need to be separated for development consideration. In the upland areas, horticulture developments with sprinkler or drip irrigation systems are most appropriate. Non-conventional irrigation development could be introduced in this zone. Several success stories are available as Madan Pokhara of Palpa District. Irrigation system development in the existing FMIS also should be considered depending on the topography of the command areas. Proper land evaluation and introducing appropriate cultivation and development technology need to be formulated. Similarly in the low land valleys, large tars are to be considered in a separate development package. Hence for the Mid Hill zone the following packages are 
recommended.

Package - I Upland Area - topography sloping lands

- Non-conventional Irrigation Technology as sprinkler, drip, rain harvesting, local small FMIS.

- Agriculture practice should be horticulture, non-rice cereals, vegetable, and other crops.

Package - II Lowland Area - topography valleys, tars, and flat plains

Numerous Farmers Managed Irrigation System exists in the valleys and terrace lands of the MidHill zones. Rehabilitation of these existing systems, and introduction to a new rain fed areas are possible. Development works in this case needs intensive study and technological variations for the irrigation system design. Possible options are:

- Conventional intake, conveyance and distribution systems.

- Possibility of pumping schemes from the snow fed large perennial rivers as Kaligandaki, Marshyangdi, Mahakali, Karnali, Bheri, etc.

- Small dam and small reservoir schemes at the small catchment and drainage areas. This option has not yet been applied so far, but possibilities are there in the interior valleys of Kaligandaki and other river basins.

- There are many options for the agriculture development in this area, with conventional or new technology.

\section{Terai}

In fact, Terai region is the main development zone where there are many possibilities of improvements either in agriculture, or in industry, or in any other sector. That is why the development works should have been planned in harnessing the potentialities of agriculture productions utilization as sugarcane, cotton, beans, etc. In the irrigation sector the packages of developments could be made as follows:

Package - I Large Farmer Managed Irrigation systems as (i) Rani Jamara and Kularia, (ii) Sorah Chhatish, and (iii) Panch Tappa etc. These large irrigation systems might cover more than 50,000 ha. of irrigable land.

Package - II Reconstruction and Rehabilitation of defunct Farmer's Managed Irrigation Systems like Pahele Bandh, Kajarar etc. It will cover mainly FMIS of 200 to 2000 ha. sizes of systems in Terai.

Package - III Groundwater Development in the rain fed areas not having surface irrigation systems.

Package - IV There are possibilities of developing irrigation systems in lift schemes. This needs keen attention and monitoring for its sustainability. Although, due to high cost of operation these systems are said to be unfeasible or failure, but in reality these systems are working and benefiting the farmers till date as the cases of Koshi Pumps, Narayani Lift, and Marchawar Irrigation Systems.

Package - V Reservoir Development in the Foothills could be developed to store the rainy season excess water and utilizing the same during winter and dry period. There are numerous places, which are viable to build reservoirs. Example of the existing Banganga Irrigation System could be taken.

Achyut Man Singh, BE (Civil), M. Sc. in Soil and Water Management from The Netherlands is an Irrigation Specialist. He served in the Nepal Department of Irrigation for 22 years, and 20 years in the private sector mostly in the field of irrigation and Water Resources engineering. He served a number of assignments for the Asian Development Bank, and the World Bank. At present, he is a consultant affiliated with SILT Consultant Pvt Ltd as Senior Technical Adviser in watershed management, irrigation, and flood control project in Eastern Chitwan sponsored under Swiss Agency for Development and Cooperation $(S D C)$.

Corresponding E-mail: achyutmsingh@gmail.com

\section{Footnote}

1. World Bank (WB) and Asian Development Bank (ADB) financed the irrigation sector projects Irrigation Line of Credit Pilot project (ILC), Nepal Irrigation Sector Project (NISP), Irrigation Sector Project (SIP), Second Irrigation Sector Project (SISP), Irrigation and Water Resources Management Project (IWRMP), and Community Managed Irrigated Agriculture Sector Project (CMIASP). The last two projects are currently running.

\section{Bibliography}

Project Completion Report, Nepal Irrigation Sector Project; World Bank (WB) assisted to Nepal, submitted by TA Team (Royds consultant Pvt. Ltd in association with CMS and MULTI consultants pvt Ltd), Kathmandu June 2004.

Project Completion Report, Second Irrigation Sector Project; Asian Development Bank (ADB) assisted to Nepal, prepared by SILT Consultatnt Pvt Ltd. June 2003.

Irrigation Management Transfer Project - Project Completion Report; ADB publication, 2004.

Integrated Consultants Nepal; Diagnostic Study of Chandra Canal Irrigation System; Department of Irrigation's Study Report, 1998.

The Tenth Plan (Poverty Reduction Strategy Paper), 2002 - 2007; His Majesty's Government, National Planning Commission, Kathmandu Nepal - July 2003.

CBS 2003,2011 
Overview of the Planning in three physiographic regions is illustrated in the attached figures as below:

\section{INTEGRATED DEVELOOPMENT APPROACH CONCEPTUAL FLOW DIAGRAM}

Sheet -1

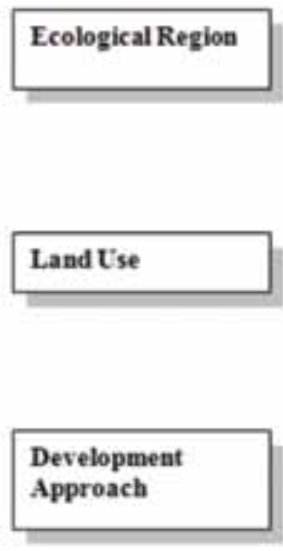

Appropriate
Technology
Input

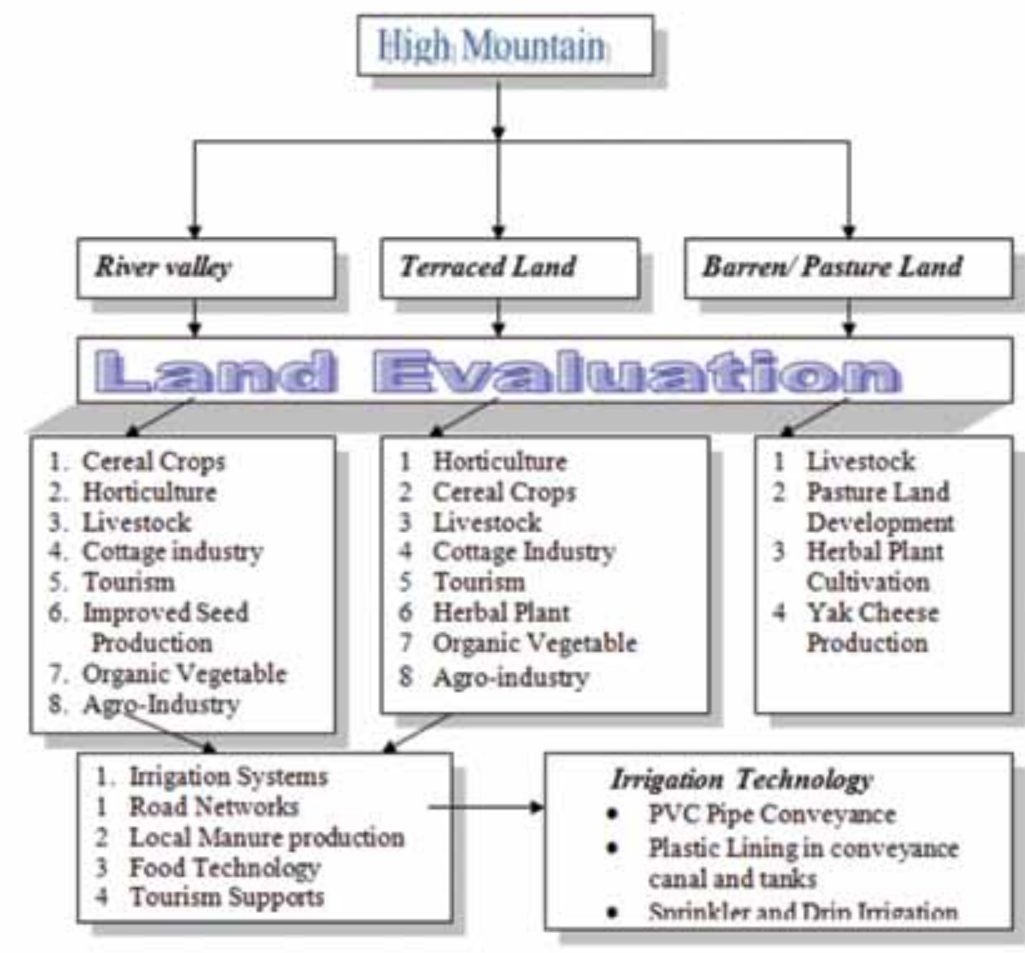

\section{INTEGRATED DEVELOOPMENT APPROACH CONCEPTUAL FLOW DIAGRAM}

Sheet - 2
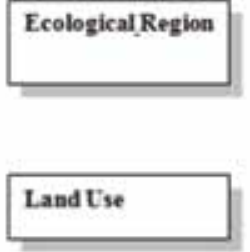

\section{Development Approach}

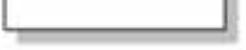

\begin{tabular}{|l|}
\hline $\begin{array}{l}\text { Appropriate } \\
\text { Technology } \\
\text { Input }\end{array}$ \\
\hline
\end{tabular}

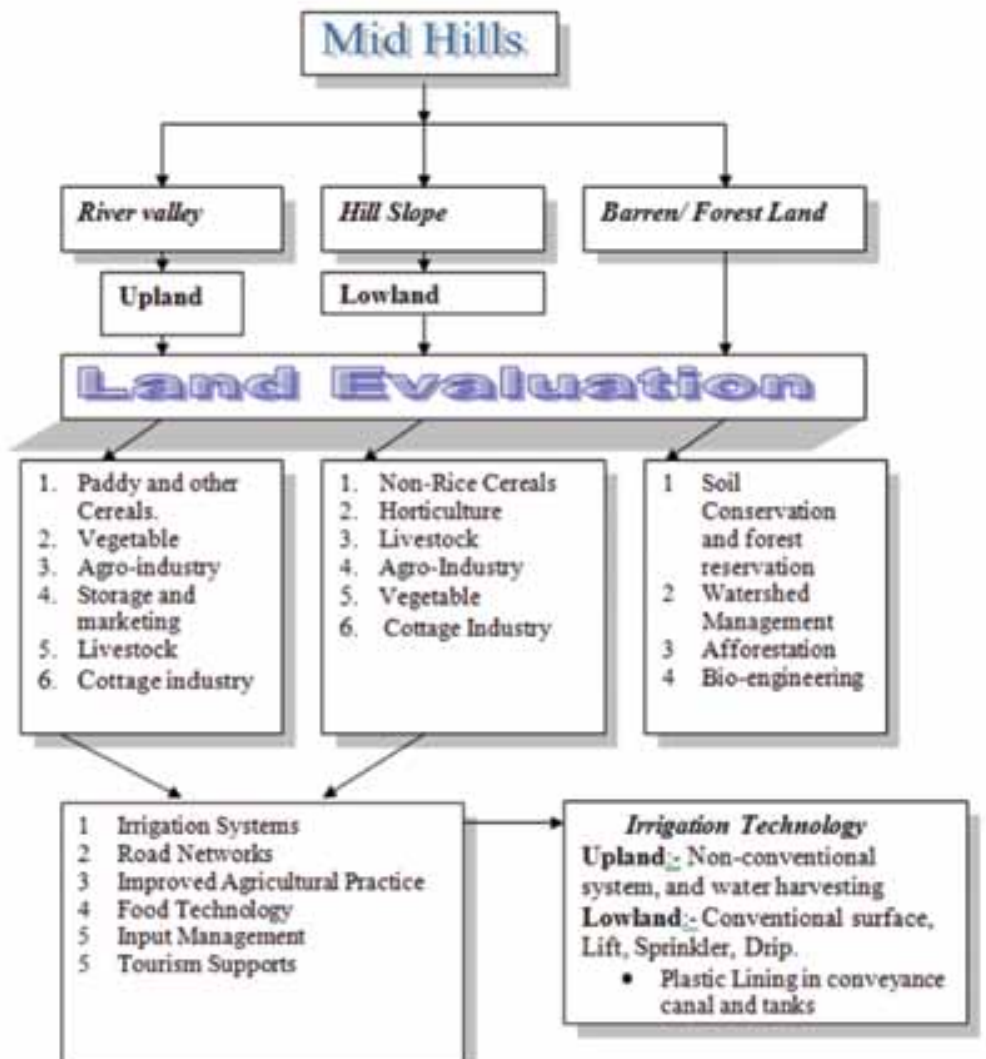




\section{INTEGRATED DEVELOOPMENT APPROACH CONCEPTUAL FLOW DIAGRAM}

Sheet - 3

\section{Ecological \\ Region}

\section{Land Use}

Development Approach

Appropriate

Technology

Input

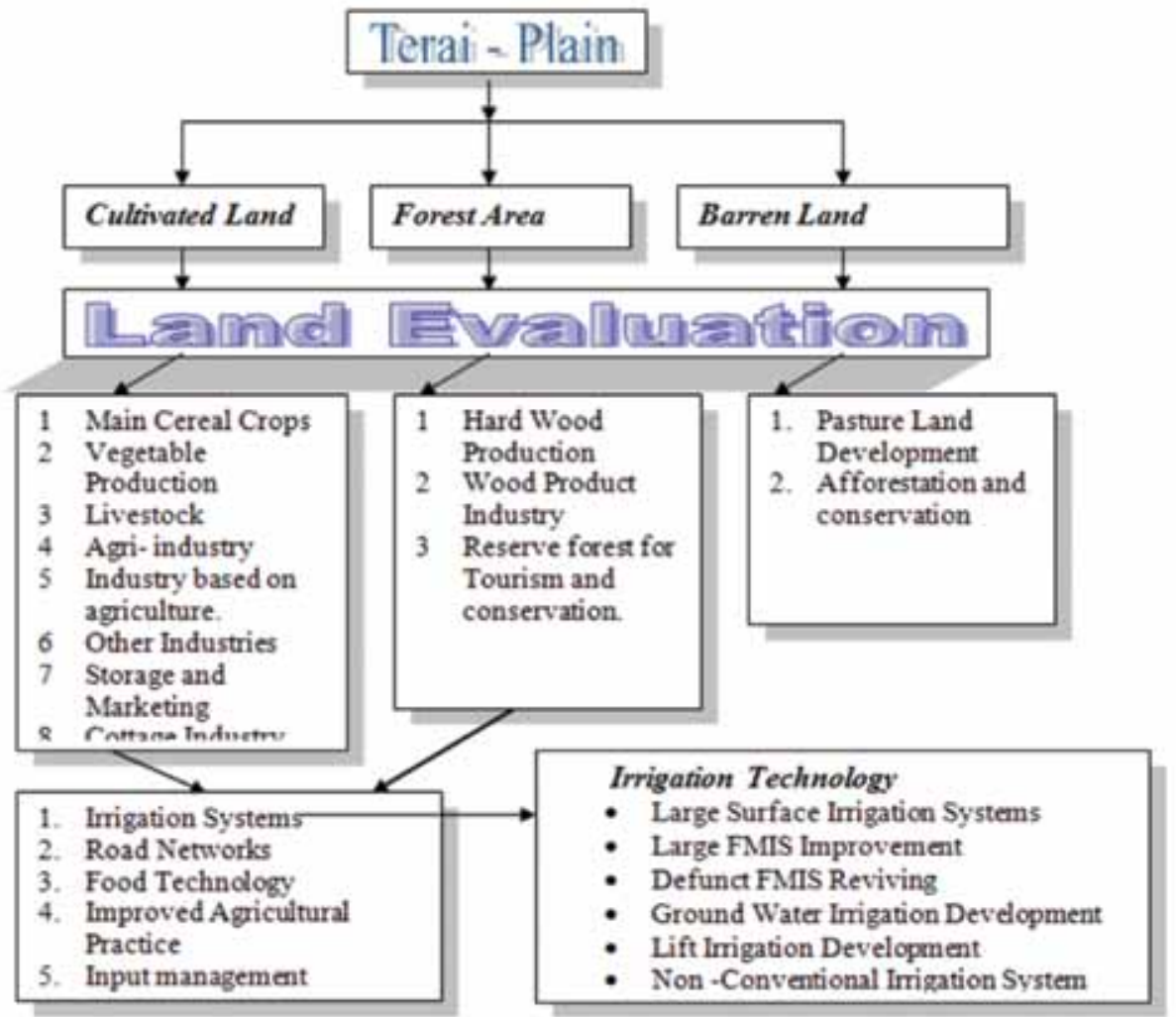

